\title{
Pengaruh asupan tinggi fruktosa terhadap tekanan darah
}

\author{
Desmawati \\ Bagian Ilmu Gizi Fakultas Kedokteran Universitas Andalas
}

Korespondensi: Desmawati,email: desmawati13@gmail.com

\begin{abstract}
Abstrak
Peningkatan jumlah konsumsi fruktosa, terutama dalam bentuk (high fructose corn syrup) HFCS, mempunyai hubungan yang erat dengan peningkatan tekanan darah. Artikel ini bertujuan untuk membahas pengaruh asupan tinggi fruktosa terhadap tekanan darah. Artikel ini ditulis berdasarkan review beberapa literatur dengan berbagai metode penelitian. Hasil penelusuran literatur didapatkan bahwa fruktosa dapat meningkatkan tekanan darah melalui beberapa mekanisme, meliputi peningkatan absorpsi natrium di usus halus, dan meningkatkan pembentukan asam urat, serta menstimulasi sistem saraf simpatik. Selain itu, fruktosa juga dapat meningkatkan regulasi sistem renin angiotensin yang merupakan mediator disfungsi vaskuler dan stres oksidatif. Mekanisme fruktosa dalam meningkatkan tekanan darah masih belum jelas, namun beberapa penelitian telah dilakukan untuk menggali hal tersebut.
\end{abstract}

Kata kunci: fruktosa; tekanan darah; hipertensi; asam urat

\section{Abstract}

Increasing the fructose consumption, especially high fructose corn syrup (HFCS), has close links with increased blood pressure. This article aim to elaborate the effect of high fructose intake to blood pressure. Several literature with several study design has been reviewed. This reviewed result that fructose can raise blood pressure by several mechanisms, including increased sodium absorption in the small intestine, increases the formation of uric acid, and stimulates the sympathetic nervous system. In addition, fructose can also improve the regulation of the renin-angiotensin system is a mediator of vascular dysfunction and oxidative stress. The mechanism of fructose in raising blood pressure is still unclear, but several studies have been conducted to explore it.

Keywords: fructose; blood pressure; hypertension; uric acid 


\section{PENDAHULUAN}

Hipertensi adalah penyakit multi faktorial yang prevalensinya meningkat dari tahun ke tahun. Menurut data dari World Health Organization (WHO) hipertensi menyebabkan 12,8 persen kematian secara global. Data epidemiologi di negaranegara Asia Tenggara menyebutkan terdapat peningkatan tekanan darah sebesar $36 \%$ dalam kurun waktu 30 tahun. ${ }^{1}$ Peningkatan tekanan darah di Indonesia sebesar $\quad 37,4 \%$ sejak 1980-2008. Kejadiannya lebih besar pada laki-laki (38,9\%) dibandingkan perempuan $(36,0 \%) .^{2}$ Prevalensi hipertensi di Indonesia pada tahun 2007 adalah sebesar $31,7 \% .^{3}$

Peningkatan tekanan darah dipengaruhi oleh banyak faktor, di antaranya aktivitas fisik dan pola makan yang tidak sehat. Pola makan yang tidak sehat di antaranya adalah terjadinya peningkatan konsumsi karbohidrat dalam bentuk gula. Marriott $\mathrm{dkk}^{4}$ menyatakan bahwa konsumsi gula terutama fruktosa lebih tinggi pada usia muda, berkisar antara 55-75 gram/hari. ${ }^{5}$

Gula atau pemanis tambahan mengandung fruktosa dan glukosa sekaligus, namun yang paling berpengaruh dalam peningkatan tekanan darah adalah fruktosa. Fruktosa adalah derivat gula tebu atau bit yang banyak ditemukan dalam buah-buahan dan sayuran. Sejalan dengan perkembangan teknologi, fruktosa diproduksi dalam bentuk high fructose corn syrup (HFCS). ${ }^{6}$ Produk fruktosa ini merupakan gula yang sangat manis dan harganya murah, sehingga pemakaian HFCS sebagai pemanis tambahan oleh industri makanan meningkat. ${ }^{7,8}$

Peningkatan jumlah konsumsi fruktosa, terutama dalam bentuk HFCS, mempunyai hubungan yang erat dengan peningkatan tekanan darah. ${ }^{5,9-11}$ Namun, hasil penelitian ini masih belum konsisten. ${ }^{12,13,14}$ Makalah ini ditulis untuk mengetahui pengaruh asupan tinggi fruktosa terhadap peningkatan tekanan darah.

\section{METODE}

Artikel ini ditulis berdasarkan review yang dilakukan pada beberapa literatur atau jurnal yang membahas tentang asupan fruktosa dan tekanan darah. Jurnal yang direview tidak dibatasi berdasarkan desain penelitian, baik yang dilakukan pada hewan maupun pada manusia.

\section{HASIL DAN PEMBAHASAN}

Fruktosa adalah monosakarida yang merupakan isomer glukosa $\left(\mathrm{C}_{6} \mathrm{H}_{12} \mathrm{O}_{6}\right)$ dalam bentuk heksosa yang mengandung gugus karbonil sebagai keton. Fruktosa secara alami dikonsumsi dalam bentuk sukrosa. ${ }^{6}$ Sukrosa ini juga digunakan sebagai pemanis tambahan dalam bahan makanan dan minuman.

Pemakaian gula sebagai pemanis tambahan semakin lama semakin meningkat. Peningkatan jumlah konsumsi gula juga diiringi oleh perubahan jenis dan sumber gula. Fruktosa yang dikonsumsi oleh penduduk Amerika pada tahun 1900, sekitar 15 gram/hari dan berasal dari buah 
dan sayur. Setelah perang dunia kedua konsumsi fruktosa meningkat menjadi 24 gram/hari. Hal ini didukung oleh kemajuan teknologi dalam produksi gula. Sejak tahun 1977 mulai diproduksi HFCS yang digunakan secara luas dalam industri makanan karena sangat manis dan murah. ${ }^{15}$

Fruktosa dikenal juga dengan nama levulosa atau gula buah merupakan monosakarida yang paling manis yang banyak ditemukan pada buah-buahan, madu dan sayuran. Sebagian besar buahbuahan mengandung $1-7 \%$ fruktosa, atau bahkan lebih banyak. Fruktosa juga terdapat dalam sayuran dan madu.,16 Sumber terbanyak fruktosa adalah sukrosa, yaitu disakarida yang merupakan derivat gula tebu dan gula bit. Sukrosa terdiri dari $50 \%$ glukosa dan $50 \%$ fruktosa. ${ }^{8}$

Fruktosa juga diproduksi melalui proses isomerasi glukosa dari jagung dan ditambahkan ke dalam minuman ringan, serta sebagai pemanis makanan lain dalam HFCS. ${ }^{6}$ HFCS terdiri dari fruktosa bebas dan glukosa dengan konsentrasi bervariasi, namun yang terbanyak adalah 55\% fruktosa dan $45 \%$ glukosa. Pemanis ini banyak ditemukan dalam minuman ringan, kue kering, makanan pencuci mulut, dan makanan olahan lainnya., ${ }^{7,8}$

Fruktosa di absorpsi di jejunum melalui GLUT5 sebagai transporter. ${ }^{17}$ GLUT5 terdiri dari 501 residu asam amino dan diekspresikan di jejunum (pada membran apikal dan basolateral), tetapi Ribonucleic Acid messenger (mRNA) GLUT5 ditemukan juga di ginjal, otot rangka, adiposit, mikroglia dan sawar darah otak. GLUT5 merupakan transporter khusus untuk fruktosa. Ekspresi GLUT5 ini sedikit sekali ditemukan di sel $\beta$-pankreas, sehingga efek fruktosa untuk menstimulasi sekresi insulin sangat kecil. Glut2 diekspresikan di membran basolateral enterosit dan bisa sebagai transporter fruktosa dan glukosa. ${ }^{6}$

Proses absorpsi fruktosa hanya dilakukan oleh GLUT5 saja jika jumlah asupan fruktosa tidak berlebihan. Namun, pada keadaan asupan fruktosa yang berlebih maka GLUT5 dan Glut2 akan di upregulation sebagai respons peningkatan fruktosa di lumen usus. Pada keadaan ini, Glut2 akan diprovokasi untuk diekspresikan di bagian membran apikal dan bersama-sama dengan GLUT5 akan membantu penyerapan fruktosa. 6,18,19

Jumlah absorpsi fruktosa tidak tergantung pada konsentrasi glukosa dalam darah, bahkan pada konsentrasi glukosa sangat tinggi pun, absorpsi fruktosa tetap berlangsung. Absorpsi fruktosa justru akan meningkat jika konsumsi glukosa meningkat. Hal ini terjadi karena pada saat glukosa diabsorpsi mengikuti gradien konsentrasi, glukosa akan membawa serta fruktosa, yang absorpsinya melawan gradien konsentrasi. Kecepatan absorpsi fruktosa lebih lambat dari pada absorpsi glukosa dan galaktosa, namun lebih cepat jika dibanding xylitol atau sorbitol. ${ }^{19}$

Absorpsi fruktosa dipengaruhi oleh umur. Semakin tua umur maka kemampuan absorpsi fruktosa semakin berkurang. makanan lain yang dikonsumsi bersamaan juga mempangaruhi penyerapan fruktosa. 
Sumber makanan non karbohidrat terutama asam lemak jenuh akan meningkatkan absorpsi fruktosa, sedangkan serat akan menghambat absorpsinya. ${ }^{14,17}$

Fruktosa diabsorpsi di usus halus dan masuk ke hati melalui vena porta. Sebanyak $50-70 \%$ fruktosa yang diabsorpsi, dimetabolisme di hati dan sisanya dikeluarkan melalui ginjal. $^{8}$ Fruktosa masuk ke hepatosit melalui transporter Glut2. ${ }^{17}$ Di hati, fruktosa akan di-fosforilasi menjadi fruktosa-1-fosfat oleh enzim fruktokinase, kemudian dipecah menjadi gliseraldehid dan dihidroaseton fosfat oleh hepatic aldolase. Dihidroaseton fosfat adalah metabolit intermediet pada jalur glikolisis dan glukoneogenesis. $6,8,19$

Gliseraldehid bisa dikonversi menjadi metabolit intermediet glikolisis oleh beberapa enzim hati, kemudian diubah menjadi glukosa dan disimpan dalam bentuk glikogen. Dihidroaseton fosfat dan gliseraldehid ini akan diubah menjadi asetil-CoA yang masuk ke dalam rantai pernafasan menghasilkan adenosin trifosfat (ATP), atau membentuk gliserol dan menghasilkan trigliserida. Hal ini dapat menyebabkan peningkatan trigliserida serum setelah mengonsumsi fruktosa. ${ }^{6,8,19}$

Kadar fruktosa serum merupakan gambaran dari keseimbangan antara absorpsi di usus, ekstraksi oleh hati, ambilan di jaringan lain, serta filtrasi dan ekskresi glomerulus. Penelitian pada tikus, didapatkan bahwa konsentrasi fruktosa darah tidak berbeda bermakna antara tikus yang diberi diet tinggi fruktosa dibandingkan kontrol yang hanya diberi air biasa, tetapi ada perbedaan yang bermakna pada kadar fruktosa urine. ${ }^{20}$

Metabolisme fruktosa berbeda dengan metabolisme glukosa. Fruktosa masuk ke dalam sel tanpa perantara insulin dan hanya sebagian kecil yang ikut dalam metabolisme glukosa. Fruktosa juga tidak menstimulasi pelepasan polipeptida inhibitor gaster yang akan menstimulasi insulin. Perbedaan lainnya adalah konsumsi fruktosa tidak meningkatkan kadar hormon leptin, sedangkan glukosa merangsang pelepasan hormon leptin. Pemakaian fruktosa yang lama akan terjadi resistensi leptin. ${ }^{21,22}$ Metabolisme glukosa dipengaruhi oleh jumlah ATP dan sitrat dalam tubuh, sedangkan metabolisme fruktosa tidak terpengaruh. Fruktosa akan dibentuk menjadi gliserol, sedangkan glukosa di simpan dalam bentuk glikogen. Glikogen ini akan dipecah kembali menjadi glukosa apabila tubuh membutuhkan energi. ${ }^{8}$

Fruktosa yang tidak dimetabolisme diekskresikan melalui urine. Kadar fruktosa urine ini merupakan gambaran jumlah asupan fruktosa yang sebenarnya. Oleh sebab itu, penilaian asupan fruktosa sebaiknya dikonfirmasi dengan kadar fruktosa urine untuk menghindari kesalahan dalam pelaporan atau pencatatan asupan. ${ }^{20}$

Konsumsi fruktosa dalam jumlah yang besar atau jangka waktu yang lama, dapat menyebabkan terjadinya gangguan metabolik seperti peningkatan sintesis trigliserida, meningkatkan penimbunan 
lemak di hati yang akan memicu terjadinya resistensi insulin. Resistensi insulin akan berlanjut menjadi berbagai penyakit seperti diabetes melitus dan hipertensi. Metabolisme fruktosa yang memerlukan banyak ATP akan menyebabkan terbentuknya asam urat melalui senyawa antara adenosin monofosfat (AMP) dan inosin monofosfat (IMP). Pembentukan asam urat yang berlebihan akan menyebabkan hiperurisemia dan akhirnya menimbulkan penyakit gout atau pirai. Hiperurisemia ini juga dapat menyebabkan kerusakan endotel pembuluh darah yang akhirnya akan menimbulkan peningkatan tekanan darah..$^{8,17,23}$

Diet tinggi fruktosa dapat meningkatkan absorpsi garam di jejunum dan absorpsi air. Peningkatan volume cairan ekstraseluler pada hewan yang diberi fruktosa akan mengakibatkan penurunan ekspresi renin di ginjal sebesar $45 \%$ dan peningkatan tekanan darah yang signifikan. ${ }^{24} \mathrm{Hal}$ ini membuktikan bahwa fruktosa dapat menginduksi peningkatan tekanan darah melalui peningkatan absorpsi garam di usus kecil. Efek ini akan lebih nyata jika asupan tinggi fruktosa disertai dengan asupan tinggi garam. ${ }^{24}$ Namun, peningkatan tekanan darah yang disebabkan oleh fruktosa ini bersifat reversibel dengan terapi anti hipertensi. Tekanan darah akan meningkat 2 minggu sejak mengonsumsi fruktosa terus menerus, namun akan turun jika diberi terapi anti hipertensi. ${ }^{25}$

Konsumsi fruktosa dapat meningkatkan regulasi sistem renin angiotensin yang merupakan mediator disfungsi vaskuler dan stres oksidatif. Hal ini terbukti dengan adanya peningkatan beberapa indikator stres oksidatif dalam plasma yaitu hidrogen peroksida dan 8-isopostane setelah konsumsi fruktosa. Konsumsi fruktosa juga meningkatkan ekspresi gen yang menggambarkan adanya stimulasi sistem renin angiotensin vaskuler dan jaringan kardial. ${ }^{25}$

Hal ini juga terlihat dari penurunan ekspresi protein eNOS dan SIRT1 setelah pemberian fruktosa. NO yang merupakan ekspresi protein eNOS, merupakan vasodilator yang kuat. Apabila terjadi penurunan kadar NO, maka akan terjadi vasokonstriksi pembuluh darah yang akan menimbulkan peningkatan tekanan darah. $^{26}$

Pemberian fruktosa juga meningkatkan produksi superoksida yang dapat memicu kerusakan endotel. Disfungsi endotel juga merupakan efek dari ekspresi molekul inflamasi yaitu Intercellular Adhesion Molecule 1 (ICAM1) yang diinduksi oleh pemberian fruktosa, yang meningkat tergantung pada dosis dan lama pemberian. Mekanisme ini mungkin berperan dalam penurunan ekspresi eNOS, yang akan menghasilkan NO. NO bisa mencegah upregulation ICAM1. Disfungsi endotel juga bisa disebabkan oleh peningkatan stres oksidatif. Stres oksidatif diinduksi oleh fruktosa melalui peningkatan konsentrasi asam urat intrasel dan pembentukan Advanced Glycation Endproducts (AGEs). Asam urat menyebabkan peningkatan ekspresi dan 
aktivasi NADPH oksidase di adiposit, sel otot polos vaskuler, dan pada ginjal. ${ }^{25,26}$

Sebagian fruktosa yang dimetabolisme di hati dikonversi menjadi asam lemak melalui proses lipogenesis de novo. Asam lemak ini dilepaskan ke dalam aliran darah bersama Very Low Density Lipoprotein (VLDL). Hal ini menyebabkan terjadinya ketidakseimbangan komponen lipid darah sehingga terjadi dislipidemia. ${ }^{27}$ Konsumsi tinggi fruktosa dalam waktu yang lama dapat menyebabkan terjadinya resistensi leptin. Resistensi leptin sering kali menimbulkan kelebihan asupan energi sehingga terjadi obesitas. ${ }^{17}$

Faktor eksternal yang mempengaruhi tekanan darah adalah faktor yang berasal dari luar pembuluh darah tetapi berperan dalam mempengaruhi tekanan darah, baik secara langsung atau tidak. Faktor eksternal itu di antaranya asupan makanan yang tidak seimbang seperti asupan tinggi karbohidrat terutama gula dalam bentuk fruktosa. Peningkatan konsumsi gula terutama fruktosa diiringi oleh peningkatan tekanan darah yang dramatis hampir di seluruh negara di dunia. Fruktosa dikatakan memiliki pengaruh yang kuat terhadap peningkatan tekanan darah baik secara akut maupun kronis. Fruktosa dapat meningkatkan reabsorpsi natrium di usus halus. Asupan garam yang berlebihan akan menyebabkan peningkatan volume cairan yang akhirnya akan meningkatkan preload dan curah jantung. Hal ini semakin nyata jika disertai dengan kerusakan ginjal yang menyebabkan retensi natrium di ginjal. ${ }^{28}$ Di samping itu, fruktosa juga dapat menstimulasi pembentukan asam urat, merangsang aktivasi saraf simpatis dan menimbulkan stres oksidatif secara akut (Gambar 1)..$^{17,23}$

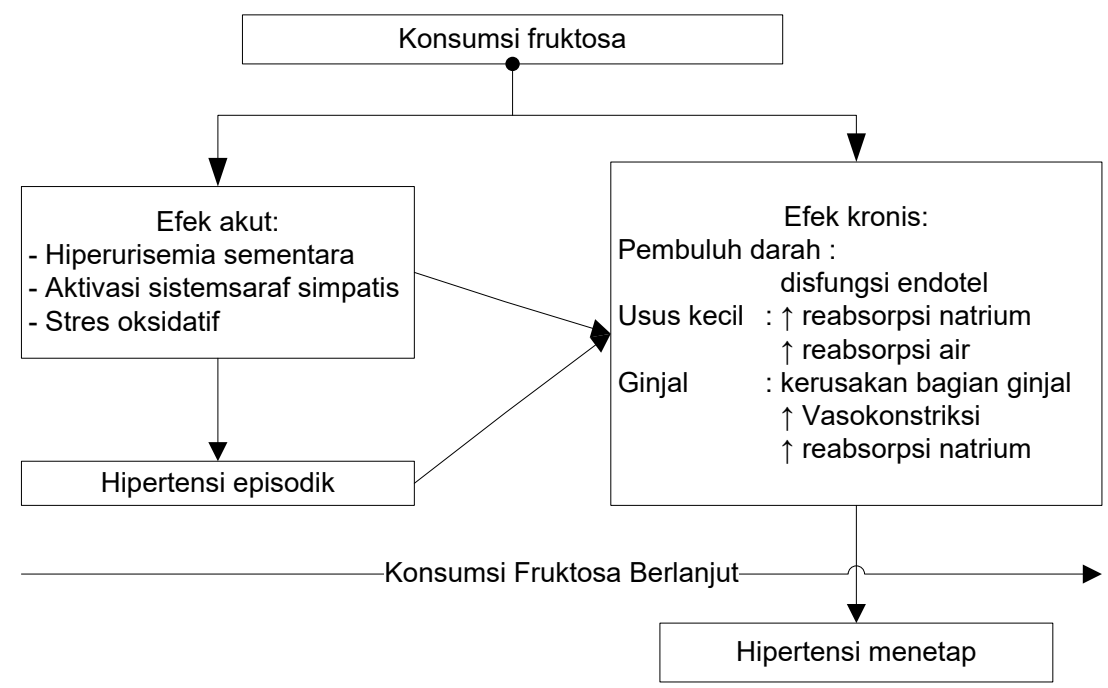

Gambar 1. Mekanisme akut dan kronis perkembangan hipertensi yang disebabkan oleh fruktosa

Selain itu, kerusakan ginjal, stres, perubahan genetik, obesitas dan penyakit lainnya juga berpengaruh terhadap peningkatan tekanan darah. Stres juga mempengaruhi pengaturan tekanan darah melalui aktivitas saraf simpatis dan 
peningkatan

produksi

hormon.

Peningkatan produksi hormon renin angiotensin akan menyebabkan konstriksi fungsional pembuluh darah dan hipertrofi struktural sehingga akan meningkatkan tahanan perifer. Tahanan perifer akan semakin meningkat jika disertai dengan obesitas dan adanya perubahan genetik. ${ }^{28}$ Penelitian terbaru menyebutkan bahwa konsumsi fruktosa yang berlebihan juga meningkatkan reabsorpsi natrium di usus halus dan retensi natrium di ginjal. Fruktosa juga menyebabkan obesitas, merangsang aktivasi saraf simpatis, menurunkan produksi NO melalui produksi asam urat, dan menyebabkan hiperinsulinemia. Kesimpulan yang dapat ditarik dari penelitian tersebut adalah fruktosa juga berperan dalam peningkatan tekanan darah. ${ }^{9-11,26}$

Fruktosa merupakan jenis gula yang paling berpengaruh dalam peningkatan tekanan darah. Hal ini disebabkan oleh efek perangsangan saraf simpatis oleh fruktosa terhadap peningkatan denyut jantung. Peningkatan denyut jantung ini berpengaruh terhadap tekanan darah. ${ }^{9}$

Fruktosa yang terdapat dalam minuman ringan pada umumnya dalam bentuk HFCS dengan kadar fruktosa yang bervariasi. Kandungan gula yang terdapat dalam minuman ringan berkisar antara $85-128 \%$ dari kadar yang tercantum pada label. Kadar fruktosa HFCS yang terdapat dalam minuman tersebut sekitar 59\% (berkisar antara $47-65 \%$ fruktosa). ${ }^{11,29}$

Peningkatan tekanan darah pada orang yang mengonsumsi fruktosa juga berhubungan dengan peningkatan kadar asam urat serum. Peningkatan konsumsi pemanis tambahan berhubungan dengan peningkatan kadar asam urat dan peningkatan TDS. Kadar asam urat meningkat $0,5 \mathrm{mg} / \mathrm{dL}$ pada remaja yang mengonsumsi pemanis tambahan dengan kategori yang lebih tinggi dibandingkan konsumsi dengan kategori yang lebih rendah. Hubungan kadar asam urat serum dan konsumsi pemanis tambahan ini tidak dipengaruhi oleh jenis kelamin dan obesitas. Peningkatan tekanan darah dengan $z$-score $0,18 .^{30}$

Peningkatan konsumsi fruktosa, dalam bentuk HFCS atau pemanis tambahan berkontribusi pada peningkatan tekanan darah melalui peningkatan asam urat serum. Asam urat serum meningkatkan tekanan darah dengan cara meningkatkan inflamasi di ginjal, aktivasi sistem renin angiotensin, menurunkan produksi nitrit oksida, dan secara akut menurunkan ekskresi natrium urine. ${ }^{30}$ Konsumsi fruktosa berhubungan dengan peningkatan kadar asam urat serum puasa. Peningkatan kadar asam urat ini dapat diturunkan secara signifikan dengan pemberian allopurinol. ${ }^{23}$

\section{KESIMPULAN}

Mekanisme peningkatan tekanan darah oleh fruktosa ini melalui peningkatan kadar asam urat plasma, yang dapat menyebabkan inflamasi di ginjal yang akhirnya akan meningkatkan tekanan darah. Perangsangan saraf simpatis oleh fruktosa juga berperan dalam peningkatan 
tekanan darah. Fruktosa juga mempengaruhi sistem renin angiotensin, menghambat sistem eNOS, dan menstimulasi stres oksidatif. Namun, pada manusia mekanisme ini belum terbukti dan perlu penelitian lebih lanjut.

\section{DAFTAR PUSTAKA}

1. WHO. Noncommunicable diseases: a major health challenge of the 21 st century. World Health Statistik. 2012:[pp34-45] Available from: http://www.who.int/gho/publications/world health statistics/EN WHS2012 Part2.pdf.

2. NCD Country Profile [database on the Internet]. 2011. Available from: http://www.who.int/nmh/countries/idn en.pdf.

3. Badan Penelitian dan Pengembangan Kesehatan. Riset Kesehatan Dasar (Riskesdas) 2007. Jakarta: Kementerian Kesehatan RI; 2007.

4. Marriott BP, Cole N, Lee E. National Estimates of Dietary Fructose Intake Increased from 1977 to 2004 in the United States. J Nutr. 2009;139: 1228S-35S.

5. Chen L, Caballero B, Mitchell DC, Loria C, Lin P-H, Champagne CM, et al. Reducing Consumption of Sugar-Sweetened Beverages Is Associated With Reduced Blood Pressure: A Prospective Study Among United States Adults. Circulation. 2010;121:2398-406.

6. Keim NL, Levin RJ, Havel PJ. Major dietary constituents and energy needs : Carbohydrates. In: Shils ME, Shike M, Ross AC, Cabelleo B, Cousins RJ, editors. Modern Nutrition in health and disease. 10 ed 2006. p. 74-6.

7. Gallagher ML. The Nutrient and Their Metabolism. In: Mahan LK, Escott-Stump S, editors. Krause's Food \& Nutrition Therapy. 12e ed. Canada2008. p. 42-5.

8. Johnson RJ, Perez-Pozo SE, Sautin YY, Manitius J, Sanchez-Lozada LG, Feig DI, et al. Hypothesis: Could Excessive Fructose Intake and Uric Acid Cause Type 2 Diabetes? Endocrine Reviews. 2009;30(1):96-116.

9. Brown CM, Dullo AG, Yepuri G, Montani J-P. Fructose ingestion acutely elevates blood pressure in healthy young humans. Am J Physiol Regul Integr Comp Physiol. 2008;294:730-7.

10. Jalal DI, Smits G, Johnson RJ, Chonchol M. Increased Fructose Associates with Elevated Blood Pressure. J Am Soc Nephrol 21. 2010;21:1-7.

11. Le MT, Frye RF, Rivard CJ, Cheng J, McFann KK, Segal MS, et al. Effects of high-fructose corn syrup and sucrose on the pharmacokinetics of fructose and acute metabolic and hemodynamic responses in healthy subjects. Metab Clin Experimental. 2012;61:641-51.

12. Dhingra R, Sullivan L, Jacques PF, Wang TJ, Fox CS, Meigs JB, et al. Soft Drink Consumption and Risk of Developing Cardiometabolic Risk Factors and the Metabolic Syndrome in Middle-Aged Adults in the Community. Circulation. 2007;116:480-8.

13. Sun SZ, Flickinger BD, Williamson-Hughes PS, Empie MW. Lack of association between dietary fructose and hyperuricemia risk in adults. Nutrition \& metabolism. 2010;7(16):1-12.

14. Forman J, Chol H, Curhan G. Fructose and vitamin C intake do not influence risk for developing hypertension. J Am Soc Nephrol. 2009;20:863-71. 
15. Lustig RH. The Fructose Epidemic. The Bariatrician. 2009:10-8.

16. Hosseini-Esfahani F, Bahadoran Z, Mirmiran P, Hosseinpour-Niazi S, Hosseinpanah F, Azizi F. Dietary fructose and risk of metabolic syndrome in adults: Tehran Lipid and Glucose study. Nutrition \& metabolism. 2011;8(50):1-8.

17. Tappy L, Kim_Anne. Metabolic effects of fructose and the worldwide increase in obesity. Physiol Rev. 2010;90:23-40.

18. Soleimani M, Alborzi P. The Role of Salt in the Pathogenesis of Fructose-Induced Hypertension. Interl J Nephrol. 2011;2011:1-8.

19. Groppher SS, Smith JL, Groff JL. Carbohydrates. Advanced Nutrition and Human Metabolism. 5 ed2009.

20. Tasevska N, Runswick SA, McTaggart A, Bingha SA. Urinary Sucrose and Fructose as Biomarkers for Sugar Consumption. Cancer Epidemiol Biomarkers Prev. 2005;14(5):1287-94.

21. Teff KL, Grudziak J, Townsend RR, Dunn TN, Grant RW, Adams SH, et al. Endocrine and Metabolic Effects of Consuming Fructose- and Glucose-Sweetened Beverages with Meals in Obese Men and Women: Influence of Insulin Resistance on Plasma Triglyceride Responses. J Clin Endocrinol Metab. 2009;94(5):1562-9.

22. Adams SH, Stanhope KL, Grant RW, Cummings BP, Havel PJ. Metabolic and Endocrine Profiles in Response to Systemic Infusion of Fructose and Glucose in Rhesus Macaques. Endocrinol. 2008;149:3002-8.

23. Perez-Poso S, Schold J, Nakagawa T, Sanchez-Lozada L, Johnson R, Lillo JL. Excessive fructose intake induces the features of metabolic syndrome in healthy adult men: role of uric acid in the hypertensive response. Interl J Obes. 2009:1-8.

24. Barone S, Fussell SL, Singh AK, Lucas F, Xu J, Kim C, et al. Slc2a5 (Glut5) is essensial for the absorption of fructose in the intestine and generation of fructose-induced hypertension. $J$ of Bio Chem. 2009;284:5056-66.

25. Nyby MD, Abedi K, Smutko V, Eslami P, Tuck ML. Vascular Angiotensin Type 1 Receptor Expression Is Associated with Vascular Dysfunction, Oxidative Stress and Inflammation in Fructose-Fed Rats. Hypertens Res. 2007;30:451-7.

26. Akar F, Uludag O, Aydın A, Aytekin YA, Elbeg S, Tuzcu M, et al. High-fructose corn syrup causes vascular dysfunction associated with metabolic disturbance in rats: Protective effect of resveratrol. Food and Chemical Toxicology. 2012;50:2135-41.

27. Chong MF-F, Fielding BA, Frayn KN. Mechanisms for the acute effect of fructose on postprandial lipemia. Am J Clin Nutr 2007. 2007;85:1511-20.

28. Vikrant S, Tiwari SC. Essensial Hypertension - Pathogenesis and Pathophysiology. J Indian Academy of Clin Med. 2001;2(3):141-61.

29. Ventura EE, Davis JN, Goran MI. Sugar Content of Popular Sweetened Beverages Based on Objective Laboratory Analysis: Focus on Fructose Content. J Obesity. 2010:1-7.

30. Nguyen S, Choi HK, Lustig RH, Hsu C-Y. Sugar-Sweetened Beverages, Serum Uric Acid, and Blood Pressure in Adolescents. J Pediatr. 2009;154:807-13. 